$\begin{array}{rrrrrrrrrrrr}\text { P } & H & 0 & T & O & G & R & A & P & H & Y & \text { PHOTOGRAPHY } \\ & & \text { A } & \text { N } & \text { D } & & \text { I } & \text { T } & \text { S } & \text { AND ITS } \\ & & & \text { S } & \text { H } & \text { A } & \text { D } & \text { O } & \text { W } & \text { SHADOW }\end{array}$ 



\section{PHOTOGRAPHY AND ITS SHADOW}

HAGI KENAAN 
STANFORD UNIVERSITY PRESS

Stanford, California

(c) 2020 by the Board of Trustees of the Leland Stanford Junior University. All rights reserved.

Frontispiece: William Eggleston, Glass in Airplane, c. 1971-1974. Dye transfer print. $30 \times 201 / 2$ inches. $76.2 \times 52.1 \mathrm{~cm}$. (C) William Eggleston. Courtesy of David Zwirner Gallery.

No part of this book may be reproduced or transmitted in any form or by any means, electronic or mechanical, including photocopying and recording, or in any information storage or retrieval system without the prior written permission of Stanford University Press.

Printed in the United States of America on acid-free, archival-quality paper

Library of Congress Cataloging-in-Publication Data

Names: Kenaan, Hagi, author.

Title: Photography and its shadow / Hagi Kenaan.

Description: Stanford, California : Stanford University Press, 2020. | Includes bibliographical references and index.

Identifiers: LCCN 2019040806 (print) | LCCN 2019040807 (ebook) | ISBN 9781503606364 (cloth) | ISBN 9781503611375 (paperback) | ISBN 9781503611382 (ebook)

Subjects: LCSH: Photography—Psychological aspects.

Classification: LCC TR183.K65 2020 (print) | LCC TR183 (ebook) | DDC 770 - dc23

LC record available at https://lccn.loc.gov/2019040806

LC ebook record available at https://lccn.loc.gov/2019040807

Cover photograph: Lee Friedlander, New York City, 1966. (C) Lee Friedlander, courtesy of Fraenkel Gallery, San Francisco.

Designed by Kevin Barrett Kane

Typeset at Stanford University Press in 10.5/15 Arno Pro with display in Mono4s Headline 
"Only now do I perceive how rude to you I am, my dear shadow." -FRIEDRICH NIETZSCHE 
This page intentionally left blank 